\title{
Effect of cell culture system on the production of human viral antigens
}

\author{
Efeito do sistema de cultura celular na produção de antígenos virais humanos
}

Ronaldo Zucatelli Mendonça'; Maria Isabel de Oliveira²; Lourdes Rehder de Andrade Vaz-de-Lima²; Rita Maria Zucatelli Mendonça ${ }^{3}$; Gildete Patriota Andrade ${ }^{4}$; Carlos Augusto Pereira ${ }^{5}$; Sumie Hoshino-Shimizu

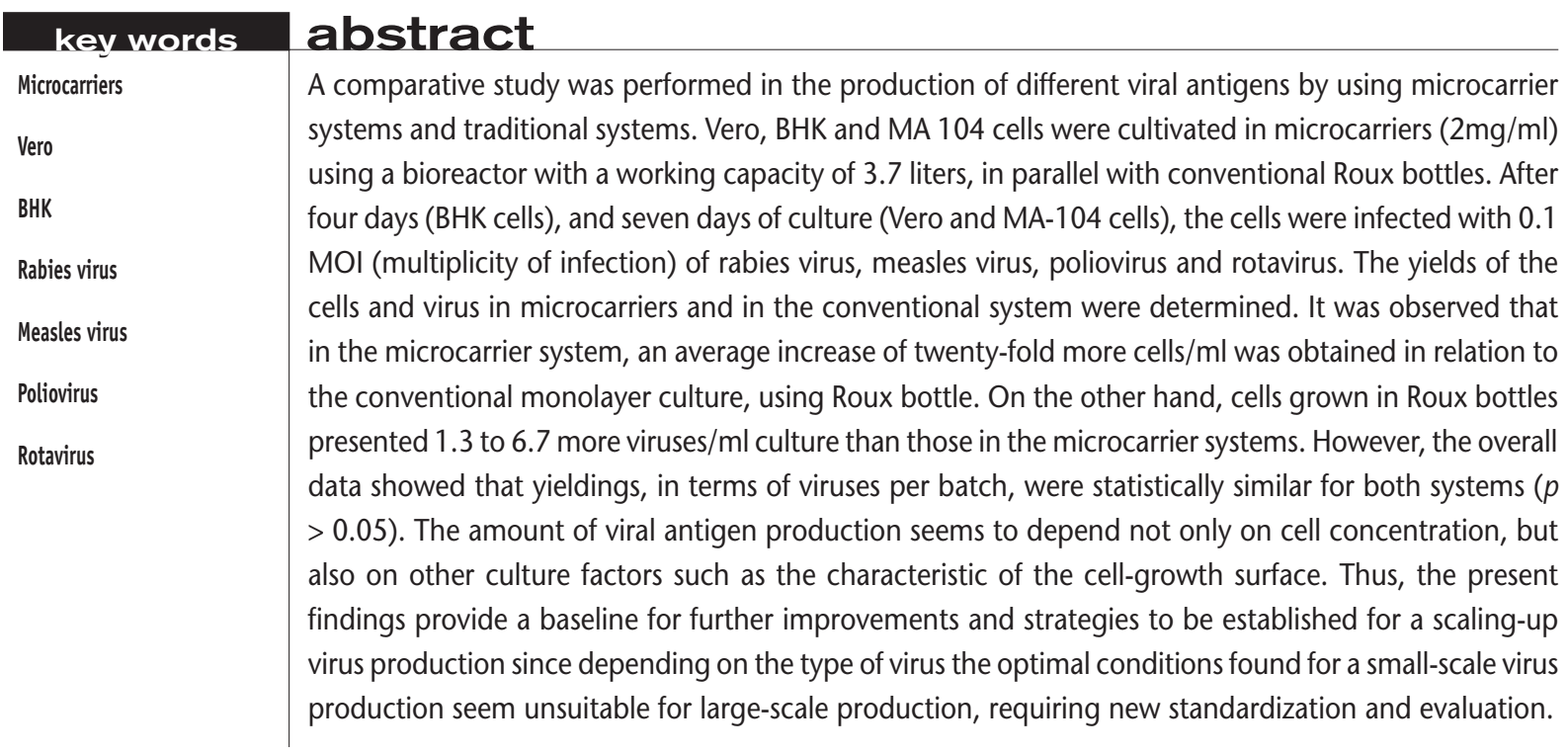

\section{resumo}

Foi realizado estudo comparativo na produção de diferentes antígenos virais usando sistema de microcarregador e sistema tradicional. Células Vero, BHK e MA-104 foram cultivadas em microcarregadores $(2 \mathrm{mg} / \mathrm{ml})$ utilizandose biorreatores com capacidade de 3,7 litros e, em paralelo, no sistema convencional com garrafas Roux. Após quatro dias de cultura para as células BHK e sete dias para as células Vero e MA-104, as células foram infectadas com 0,1 MOI (multiplicidade de infecção) de vírus da raiva, vírus do sarampo, poliovírus e rotavírus. Foi determinado o rendimento das células e dos vírus em microcarregadores e sistema convencional. Foi observado no sistema de microcarregador um aumento médio obtido de vinte vezes mais células $/ \mathrm{ml}$ em relação à cultura convencional em monocamadas, usando garrafas Roux. Por outro lado, as células que cresceram em garrafas Roux apresentaram 1,6 a 6,7 mais vírus/ml em culturas do que no sistema de microcarregador. Contudo o total das amostras em termos de vírus por grupo foi estatisticamente similar para ambos os sistemas $(\mathrm{p}>0,05)$. O rendimento na produção de antígeno viral pode depender não somente da concentração das células, mas também de outros fatores da cultura, como características do suporte no crescimento. Assim, o estudo deste parâmetro pode proporcionar uma linha de base para um futuro melhoramento e estratégias para se estabelecer um aumento em escala na produção de vírus, já que, dependendo do tipo de vírus, a ótima condição encontrada para uma produção de vírus em pequena escala pode não ser adequada para a produção em grande escala, requerendo novas padronização e avaliação. 


\section{Introduction}

Viral diseases have been extensively studied and much of the advanced knowledge was implemented in the public health services by means of virus infection surveillances, vaccination programs and diagnoses.

In control programs of virus diseases, an early diagnosis mostly performed by serological assays, as well as the prevention of virus infections by vaccination, is essential for the benefit of the population.

Thus, viral antigen productions for both vaccine and serodiagnosis are of main concern and interest for public health institutions ${ }^{(4)}$. However, a large-scale production of virus also requires a considerable amount of substract cells ${ }^{(13,14)}$. The growth of anchorage-dependent cells has been greatly facilitated by the development of microcarrier systems. This is a unit process that gives a large surface area for cell growth, in which high cell yields can be obtained in somewhat smaller culture volumes ${ }^{(15)}$.

This system has been widely employed in large-scale cell productions. Viruses( ${ }^{(8)}$ and several other biological products such as hormones, enzymes or cytokines have also been successfully obtained ${ }^{(2,12)}$, showing that this system is a suitable or promising method for large-scale productions ${ }^{(3,10)}$.

This work evaluates the microcarrier systems for different types of virus production, in comparison with their conventional systems, aiming to improve and increase the yields of routine production of virus antigens.

\section{Material and method}

\section{Cell cultures}

Vero, BHK21C13 and MA-104 cells were grown in Roux bottles or attached in microcarriers (cytodex-1 - Sigma Co.) at $2 \mathrm{mg} / \mathrm{ml}$. The cultures were performed in a Celligen Cell Culture System (New Brunswick Scientific Co.) with a working capacity of 3.71 . The cultures were initiated at a cell concentration of 6 to $9 \times 10^{4}$ cells $/ \mathrm{ml}$ in Leibovitz medium, supplemented with $5 \%$ of fetal bovine serum (FBS) and maintained at $37^{\circ} \mathrm{C}$ and $60 \mathrm{rpm}$.

\section{Virus production}

After four days of BHK cell culture being grown in suspension, it was infected with rabies virus. Vero cells on the $7^{\text {th }}$ day of culture were infected with polio, measles and rabies virus and MA-104 cells were infected with rotavirus
(SA-11). All cultures were infected with an $\mathrm{MOI}$ (multiplicity of infection) of 0.1. The infected cultures were maintained at $33^{\circ} \mathrm{C}$ until the appearance of a cytopathic effect on the measles virus, rotavirus and poliovirus. The rabies virus was collected on the $5^{\text {th }}$ day. The supernatant of the culture was harvested and the virus titre was determined. Measles virus, rotavirus and poliovirus titres were determined by infectious doses of $50 \%$ in cell culture (TCID50) and rabies virus was determined by a brain mouse inoculation test (DL50). The cultures were performed comparatively in microcarrier systems and in Roux bottles.

\section{Results}

The microcarrier systems gave five times more cells/ $\mathrm{ml}$ than those from the monolayer growth in the Roux bottles. This result must be related to the larger surface for cell growth in microcarrier systems in relation to volume. Nevertheless, the cell number per area was slightly higher in Roux bottles. The amount of cells yielded in both systems is shown in Table 1.

Although the total number of cells in microcarrier systems was higher than those of traditional systems, the virus productivity in the former systems was lower than in the latter. The titres provided by different virus in both systems are presented in Table 2. The titre differences between both systems ranged from 0.1 to $0.8 \mathrm{log}$, showing no statistical difference $(p>0.05)$, as tested by $t$ test for small number of samples ${ }^{(6)}$. The virus yieldings per cell and per milliliter are presented in Table 3. The cell grown in Roux bottles showed 1.3 to 6.7 times more viruses $/ \mathrm{ml}$ than those in the microcarrier systems, and the rotavirus gave the lowest yield in the microcarrier system among other types of virus. Nonetheless, the overall virus yieldings did not differ significantly $(p>0.05)$ between microcarrier systems and conventional systems. Also, relative virus yieldings per batch of $60 \mathrm{ml}$ were estimated, in comparison with the traditional systems (Table 4). Better results were obtained with poliovirus, followed by rabies of the Vero cells and BHK cells, measles and rotavirus.

Comparison of cell yields in Vero cell culture using Roux bottles and

Table 1 microcarriers (MC)

\begin{tabular}{lcc}
\hline Cellular yield & Cells $/ \mathrm{ml}$ & Cells $/ \mathrm{cm}^{2}$ \\
MC & $1-1.5 \times 10^{6}$ & $0.8-1.3 \times 10^{5}$ \\
Roux & $2-3 \times 10^{5}$ & $1-1.5 \times 10^{5}$ \\
\hline
\end{tabular}


Table 2 Viral titration per ml obtained in cell cultures carried out in Roux bottles and in microcarriers

\begin{tabular}{lccccc}
\hline Virus & Rabies & Rotavirus & Measles & Poliovirus & \\
System & DL50/ $0.03 \mathrm{ml} \times \log 10$ & DICT50/mlxlog10 & DICT50/ ml x log10 & & \\
& Vero & BHK & MA-104 & Vero & \\
Roux & 5.5 & 5.8 & 5.6 & 8.1 & 11.7 \\
MCs & 5.2 & 5.4 & 4.8 & 7.4 & 11.6 \\
\hline
\end{tabular}

\section{Table 3 Difference between the virus yields in Roux bottle system and microcarrier system}

\begin{tabular}{lcccc}
\hline & \multicolumn{3}{c}{ Virus yields } \\
Virus & DL50/cell & \multicolumn{2}{c}{ DL50/ml } \\
\cline { 2 - 5 } & Roux & MC & Roux & MC \\
Rabies (Vero) & 52 & 5.2 & $130 \times 10^{5}$ & $65 \times 10^{5}$ \\
Rabies (BHK) & 104 & 8.2 & $260 \times 10^{5}$ & $102.5 \times 10^{5}$ \\
Measles & 630 & 25.1 & $1,575 \times 10^{5}$ & $313.8 \times 10^{5}$ \\
Poliovirus & $25 \times 10^{5}$ & $4 \times 10^{5}$ & $62.5 \times 10^{10}$ & $50 \times 10^{10}$ \\
Rotavirus & 2 & $0.6 \times 10^{-1}$ & $50 \times 10^{4}$ & $7.5 \times 10^{4}$ \\
\hline
\end{tabular}

\section{Virus production per batch in Roux bottle system and microcarrier system, and relative}

Table 4 yields obtained for different types of virus

\begin{tabular}{lccc} 
& \multicolumn{2}{c}{ DL50/batch* } & Relative yield (\%) \\
Virus & Roux & MC & MC/Roux \\
\hline Rabies (Vero) & $7.8 \times 10^{8}$ & $3.9 \times 10^{8}$ & 50 \\
Rabies (BHK) & $15.6 \times 10^{8}$ & $6.2 \times 10^{8}$ & 39.7 \\
Measles & $94.5 \times 10^{8}$ & $18.8 \times 10^{8}$ & 19.9 \\
Poliovirus & $37.5 \times 10^{12}$ & $30 \times 10^{12}$ & 80 \\
Rotavirus & $30 \times 10^{6}$ & $4.5 \times 10^{6}$ & 15 \\
\hline${ }^{* 60 \mathrm{ml}}$. & & &
\end{tabular}

\section{Discussion}

The cell-cultivation system using microcarriers, in which the cell adherents are grown in suspension, adhering to the microspheres, represents a very important tool for producing cells in large amounts, mainly by permitting the attainment of high-density cells as well as by facilitating the scalingup of the process, before defining a large-scale industrial production. A significant variation has been observed in the quantity of virus obtained by this system in relation to that obtained by the traditional procedure ${ }^{(1,12)}$. Also with some strains, viral titre in relation to the number of cells was observed to be greater in the traditional system ${ }^{(9,14)}$.

In this work we have studied the production of different viruses of interest to the public health laboratories and control programs, in reference to their yields obtained in cultures carried out by the traditional systems and the system of microcarriers. The differences observed in viral yields are related as much to the type of cells utilized as to the viral species in question. With rabies virus, greater titres were obtained in BHK cells than those in Vero cells. The poliovirus production was similar in both systems, showing 
the highest titres. Conversely, the rotavirus gave the lowest titres, in both studied systems.

The low replication level of this virus in microcarriers can be related to the infection mechanism, influenced by factors as few cell receptors exposed to virus, time required for infection, type of cell support for cell growth, among others. It seems that the traditional static system renders better virus growth, rather than the microcarrier system with a limited period for cell infection time, and consecutive agitation period. So, the rotavirus yield may be effectively increased, if the cells attached to microcarriers are pre-treated with tripsin. The tripsin can promote easy virus attachment to the cell, by exposing virus receptors. The infection of cells covering microcarriers with virus is very complex, differing from those of cultures carried out in a static system, mostly due to the difficulty in eliminating all the cell-growth culture medium, which may contain inhibitors of the tripsin activity, before the infection is performed, in virus-growth culture medium. In the case of rotavirus infection, the complete removal of the cell culture medium seems a critical point for virus penetrating cell.

The difference of the viral titre observed between the two systems can be related as much to the cell-growth support as to its spatial conformation ${ }^{(7)}$. In other words, the physical characteristic of the support as well as the conformation can have a great influence on cells, promoting membrane alterations and influencing messages sent inside the cells, affecting the cellular metabolism and the membrane production ${ }^{(15)}$. Utilizing glass bottles, glass microcarriers and DEAE-Dextran microcarriers, Varani et al. ${ }^{(13)}$ demonstrated an increase in the production of MRC-5, HFF and MK cells, when the support used was also of glass and flat in relation to the base of the Roux bottle. However, the production of prostaglandin by these cells, using microcarriers, was greater than that of bottles with a flat surface, and still greater when the cells were grown in microcarriers of DEAE-Dextran, confirming the importance of the type of support and the structural conformation for the internal cell activities. One of the explanations for this outcome could be the three-dimensional structure of the receptors and the fluidity with which they are altered, according to the state of the cellular susceptibility. It has been observed by Lai et al. ${ }^{(5)}$ that the membrane of the Chinese hamster ovary cells $(\mathrm{CHO})$ are more rigid when grown adhered to the microcarriers than when grown in suspension. Under such conditions, an interaction was observed between the cell and the support, occurring less flexing of the lipid chains of the cellular membrane and, consequently, reflecting in the macromolecular cell organization.

These alterations could also be occurring in the cells we used for viral production, and this could explain the variations observed in the viral titres for different systems of support we worked. The titres were higher when the virus was grown in cells adhered to a flat support than in microcarriers. These differences could be derived from the modifications that happened in the cell membranes. There are other factors, though, that could be influencing the viral yield, such as temperature, $\mathrm{pH}$, oxygen concentration and osmosis ${ }^{(11)}$, agitation velocity ${ }^{(10)}$ or the procedure of cell infection.

Our findings suggest that although some virus, such as measles virus, from the microcarrier systems showed a low yield, this fact can be compensated by the great batch volume of cell culture as demonstrated in our previous report ${ }^{(8)}$. Variables related to the infection times and cellvirus interaction may also be interfering in the final viral yield.

It has also been observed that different subtract composition of the three-dimensional conformation can be an important factor for large-scale virus production ${ }^{(13)}$, affecting the cell growth and biological properties of fibroblasts and epithelial cells. Exact knowledge of these factors is of great relevance for the optimization of virus production, being an interesting issue for public health institutions.

Thus, the present work provides a baseline to better define parameters for a scaling-up process of virus antigen production, as well as to further establish condition and strategy for large-scale production of viral antigens.

\section{References}

I. CAlJ, A. et al. High titre dog cholera virus production on cytodex 3 microcarriers culture. Arch Virl, v. 105, p. I I3-1 18, 1989.

2. CRUZ, H. J.; MOREIRA J. L.; CARRONDO M. J. Metabolically optimized BHK cell fed-batch cultures. J Biotechnol, v. 80, n. 2, p. $109-18,2000$.

3. ELIAS, C. B. et al. Enhanced growth of SF-9 cells to a maximum density of $5,2 \times 10^{7}$ cells per $\mathrm{ml}$ and production of beta- galactosidase at high cell density by fed batch cultures. Biotechnol Bioeng, v. 68, n. 4, p. 38I-8, 2000.

4. HOSHINO-SHIMIZU, S. et al. Measles serodiagnosis: production and evaluation of the IgM-measles Elisa ${ }^{\text {IAL }}$ reagent. Braz J Microbiol, v. 32, n. I, p. 70-5, 200I.

5. LAI, C. S.; HOPWOOD, L. E.; SWARTZ, H. M. Electron spin resonance studies of changes in membrane fluidity of 
Chinese hamster ovary cells during the cell cycle. Biochim Biophys Acta, v. 602, n. I, p. I 17-26, 1980.

6. LAMOTTE, M. Estadística Biológica. Principios Fundamentales. Caso de pequeñas muestras. Barcelona: Socitra SA, 1981. p. 96- 100.

7. MENDONÇA, R. Z. Metabolic active-high density Vero cell cultures on microcarriers following apoptosis prevention by galactose/glutamine feeding. J Biotechnol, v. 97, n. I, p. I3-22, 2002.

8. MENDONÇA, R.Z. Measles virus antigen obtained in a bioreactor with a microcarrier Vero cell culture. Braz J Med Biol Res, v. 27, p. 1575-87, 1994.

9. MERED, B. Propagation of poliovirus in microcarriers cultures of three monkey kidney cell lines. J Biol Stand, v. 9, p. I3745, 1981.

10. TYO, M.; WANG, D. I. C. Engineering characterization of animal cell and virus production using controlled change microcarriers. Adv Biotechnol, v. I, p. |4|-6, 1980.

I I. Van WEZEL, A. L. New approach to the production of concentrated and purified inactivated polio and rabies tissue culture vaccines. Dev Biol Stand, v. 4I, n. 159-68, 1978.

12. Van WEZEL, A. L. Large-scale animal cell cultivation for production of cellular biologicals. Dev Biol Stand, v. 60, p. 229-36, 1985.

13. VARANI, J. Substrate-dependent differences in growth and biological properties of fibroblasts and epithelial cells grown in microcarriers culture.J Biol Stand, v. 13, n. 67-76, 1985.

14. VARANI, J. A. Cell growth on microcarriers: comparison of proliferation and recovery from various substrates. J Biol Tand, v. 14, p. 331-6, 1986.

15. WANG, D. Studies on high-density cultivation of Vero cells with biosilon solid microcarrier. Clin J Biotechnol, v. 12, n. 2, p. I19-29, 1996.

\section{Mailing address}

Ronaldo Zucatelli Mendonça

Instituto Butantan

Laboratório de Imunologia Viral

Av. Vital Brasil 1.500

CEP 05503-900 - São Paulo-SP

Tel.: (11) 3726-3722, ramal 2105

e-mail: zucatelli@uol.com.br 